\title{
National institutions and global public goods Are democracies more cooperative in climate change policy?
}

\section{Journal Article}

Author(s):

Bernauer, Thomas; Bättig, Michèle B.

Publication date:

2009

Permanent link:

https://doi.org/10.3929/ethz-b-000019435

Rights / license:

In Copyright - Non-Commercial Use Permitted

Originally published in:

International Organization 63(2), https://doi.org/10.1017/S0020818309090092 


\title{
National Institutions and Global \\ Public Goods: Are Democracies \\ More Cooperative in Climate \\ Change Policy?
}

\author{
Michèle B. Bättig and Thomas Bernauer
}

\begin{abstract}
This article examines whether democracies contribute more to the provision of global public goods. It thus contributes to the debate on the effects of domestic institutions on international cooperation. The focus is on human-induced climate change, in Stern's words "the biggest market failure the world has ever seen." ${ }^{1}$ Using new data on climate change cooperation we study a cross-section of 185 countries in 1990-2004. The results show that the effect of democracy on levels of political commitment to climate change mitigation (policy output) is positive. In contrast, the effect on policy outcomes, measured in terms of emission levels and trends, is ambiguous. These results demonstrate that up until now the democracy effect has not been able to override countervailing forces that emanate from the free-rider problem, discounting of future benefits of climate change mitigation, and other factors that cut against efforts to reduce emissions. Even though democracies have had a slow start in moving from political and legal commitments (policy output) to emission reductions (policy outcomes), particularly in the transportation sector, we observe some encouraging signs. The main implication of our findings for research on international politics is that greater efforts should be made to study policy output and outcome side by side. This will help in identifying whether more democratic countries experience larger "words-deeds" gaps also in other policy areas, and whether there are systematic differences of this kind between domestic and international commitments and across different policy areas.
\end{abstract}

Political scientists have, for analytical and normative reasons, invested much time and effort in trying to understand the consequences of democracy. A large amount of research concentrates on whether democratic systems perform better in terms

The authors are grateful to Michael Bechtel, Gary Goertz, Dieter Imboden, Detlef Jahn, Anna Kalbhenn, Vally Koubi, Mira Marcus-Kalish, Christian Martin, Katja Michaelowa, Ken Oye, Matthew Paterson, Michael Ross, Gabi Ruoff, Lena Schaffer, Detlef Sprinz, Jana von Stein, Hugh Ward, and the reviewers and editors of $I O$ for highly useful comments on earlier versions of this article. This article was written in the context of the Swiss National Research Program on democracy in the twentyfirst century.

1. Stern $2007,4$. 
of poverty reduction, ${ }^{2}$ economic development, ${ }^{3}$ and environmental quality. ${ }^{4}$ At the international level, a vast literature focuses on the democratic peace hypothesis. ${ }^{5}$ International political economy scholars have examined how democracy affects conflict and dispute settlement in the global trading system, ${ }^{6}$ and how it influences compliance behavior in trade, monetary relations, and other areas. ${ }^{7}$ International relations scholars have also been interested in how democracy influences the propensity of states to engage in international commitments, for example, in the form of joining international organizations and treaties. ${ }^{8}$

The existing literature shows that the implications of democracy for solving important policy problems, both domestically and internationally, vary considerably across levels of analysis, policy problems, and empirical definitions of policy performance. For example, most studies on democratic peace find positive effects for democratic dyads, ${ }^{9}$ while the monadic effects remain disputed. The democracy effects on socioeconomic development appear ambiguous. ${ }^{10}$ In the trade area, democracies tend to escalate disputes more often. ${ }^{11}$ Several studies on environmental performance have shown that democracies perform better in terms of domestic environmental quality ${ }^{12}$ and international commitment to environmental protection, ${ }^{13}$ but the effects on transboundary environmental problem solving are less clear. ${ }^{14}$

Our contribution fills an important gap in this literature by focusing on the implications of democracy for the provision of global public goods. Most of the existing literature concentrates on the provision of domestic public goods or the international behavior of countries vis-à-vis specific other countries. The empirical focus in this article is on climate change. Within the past twenty-five years, the problem of human-induced climate change has evolved from a rather speculative scientific topic into one of the key issues on the global policy agenda. Nicholas Stern, former World Bank chief economist and author of an influential study on the economic effects of climate change, has called the latter "the biggest market failure the world has ever seen." 15 The global scientific community, as organized through the Intergovernmental Panel on Climate Change (IPCC), is largely in agreement that anthropogenic causes, and emissions from the combustion of fossil fuels in particular, are

2. See, for example, Ross 2006.

3. See, for example, Przeworski 2004.

4. See, for example, Ward 2008.

5. See, for example, Dorussen and Ward 2008.

6. See, for example, Busch 2000.

7. See, for example, Dai 2006.

8. See, for example, Hafner-Burton, von Stein, and Gartzke 2008; and Neumayer 2002.

9. See, for example, Dorussen and Ward 2008.

10. See Ross 2006; Bueno de Mesquita et al. 2001; and Plümper and Martin 2003.

11. See, for example, Busch 2000.

12. See Ward 2008; Bernauer and Koubi 2009; and Li and Reuveny 2006.

13. See Roberts, Parks, and Vásquez 2004; and Neumayer 2002.

14. Bernauer and Kuhn forthcoming.

15. Stern 2007, 4. 
to blame in large part for increasing temperatures in many areas of the world and also for increasing the global average temperature. This community also agrees that the economic and social effects of human-induced climate change are grave and potentially disastrous, notably for societies with insufficient means to adapt, and that reductions of greenhouse gas $(\mathrm{GHG})$ emissions on a large scale are required. ${ }^{16}$

The climate change issue also raises very interesting questions for scholars of comparative and international politics. It is one of the few policy challenges in the international system that corresponds very closely to standard definitions of a global public good and the tragedy of the commons. ${ }^{17}$ Everyone producing GHG emissions, no matter where on earth, contributes to increasing the risks of adverse climatic changes; everyone reducing GHG emissions contributes to the mitigation of such risks. The conventional logic of public goods theory holds that such problems are very difficult to solve, ${ }^{18}$ particularly at the global level. There is no single country or agency that can act as an effective central enforcer, and the costs arising from aggregating national preferences, casting them into collectively binding global decisions, and implementing these policies are high. Moreover, the climate change problem is a long-term, intergenerational problem and involves big scientific challenges in trying to understand the benefits and costs of problem solving. ${ }^{19}$ The obvious difficulties in implementing the 1997 Kyoto Protocol and concluding a follow-up agreement for the post-2012 period demonstrate that the prediction of public goods theory is probably correct. ${ }^{20}$

Nonetheless, when we move from the global system perspective to cross-national comparisons we observe that national contributions to the global public good of climate change mitigation vary considerably, both with respect to political commitments and emission behavior. Table 1 illustrates this point.

For example, Germany scores high on political commitment and on reducing per capita GHG emissions, as does the United Kingdom. China, India, and Iran appear as laggard countries on both accounts. Australia, Brazil, Japan, and the United States occupy the middle ground. North Korea exhibits relatively low political commitment, but its emissions have declined. Conversely, Norway performs better with respect to political commitment than to GHG reductions.

Even more surprising from the viewpoint of public goods theory, several small countries and even some subnational political units (for example, U.S. cities and states) have adopted ambitious mitigation targets. Small actors can, individually, make only a small contribution to solving the overall problem and should thus have an especially strong incentive to free-ride on the efforts of bigger actors.

Why, apparently, do some countries contribute more to the global public good of climate change mitigation than others? Can we say anything generic about the

16. See Stern 2007; and IPCC 2007.

17. Hardin 1968.

18. See, for example, Barrett 2005; and Sandler 2004.

19. IPCC 2007.

20. See, for example, Cass 2006; and Victor 2001. 
TABLE 1. Differences in climate change policy across countries

\begin{tabular}{lccc}
\hline Country & Commitment & $\begin{array}{c}\text { GHG/cap change } \\
\text { 1980-2004 (\%) }\end{array}$ & $\begin{array}{c}\text { GHG/cap change } \\
\text { 1990-2004 (\%) }\end{array}$ \\
\hline Australia & 0.65 & 0.7 & 0.9 \\
Brazil & 0.58 & 0.5 & 1.8 \\
China & 0.65 & 4.0 & 4.4 \\
Germany & 0.85 & -1.3 & -1.3 \\
India & 0.60 & 3.9 & 2.9 \\
Indonesia & 0.56 & 2.4 & 4.5 \\
Iran & 0.45 & 0.9 & 3.9 \\
Japan & 0.65 & -2.8 & 0.8 \\
North Korea & 0.52 & 1.0 & -4.6 \\
Norway & 0.83 & -0.5 & 1.8 \\
United Kingdom & 0.95 & -0.2 & 0.6 \\
United States & 0.63 & & 0.1 \\
\hline
\end{tabular}

Notes: The commitment variable ranges from 0 to 1 , with 1 expressing the strongest political commitment to climate change mitigation. This variable is defined in the empirical design section below. GHG/cap is defined as the average annual change in per capita GHG emissions, excluding land use change, in $\mathrm{CO}_{2}$ equivalents.

Sources: Bättig, Brander, and Imboden 2008; CAIT 2008.

factors that motivate countries to behave more (or less) cooperatively? The economics literature views environmental outcomes (such as GHG emissions) as determined largely by economic factors, like economic output, income, industrial structure, trade, and so on. ${ }^{21}$ On occasion, economic models include some political control variables, but without much theoretical discussion. Moreover, economic models pay little attention to policy output (political commitments), whereas the political science literature on environmental policy concentrates quite heavily on explaining policy output, rather than policy outcomes.

We address both gaps in this article. First, we concentrate on examining the effects of political institutions on climate change mitigation efforts. It is almost a truism among political scientists that domestic institutions affect international politics. But there is much less agreement, theoretically and empirically, on which particular institutional properties shape policy outputs and outcomes. ${ }^{22}$ We contribute to this research by studying whether and how democracy affects national behavior with respect to the provision of global public goods in the case of climate change mitigation. We focus on the effects of democracy because democracy is arguably the most fundamental feature that distinguishes national political systems in global comparison. Some of the theoretical arguments and empirical findings reported in the existing literature support the claim that democracy is conducive

21. See, for example, Cole and Neumayer 2005; and Antweiler, Copeland, and Taylor 2001.

22. See, for example, Przeworski 2004. 
to international public goods provision in the environmental realm. ${ }^{23}$ But others are ambiguous or even negative. ${ }^{24}$ We will develop and test the hypothesis that, ceteris paribus, democracies are more cooperative with respect to climate change mitigation efforts. We theorize that the democracy effect hinges on whether the median voter and/or influential interest groups prefer more public goods provision and conclude that both the demand for, and supply of, climate mitigation measures are likely to be stronger in democracies. Furthermore, we argue that the democracy effect on environmental policy outcome is likely to be weaker than on policy output.

The empirical testing was done on a cross-section of 185 countries in 19902004. We used new data on climate change cooperation that allowed us to study the effects of democracy on policy output and policy outcomes side by side. The existing literature has focused either on one or the other dependent variable. Our results confirm that distinguishing between policy output and policy outcome is important. Democracies contribute more to the global public good in terms of policy output. In contrast, the democracy effect on policy outcomes is ambiguous.

Our interpretation of these results is that in moving from political commitments to reductions of GHG emissions, the democracy effect has, up to this point in time, not been able to override countervailing forces that emanate from the free-rider problem, the discounting of future benefits of climate change mitigation, and other factors that cut against efforts to reduce emissions. We also observe that democratic countries are experiencing greater difficulties in coping with emissions from transportation, where emission cuts are most likely to require restrictions on personal freedom (mobility). The main implication of our findings for research on international politics more broadly is that greater efforts should be undertaken to study policy output and outcome side by side. This will help in identifying whether more democratic countries also experience larger "words-deeds" gaps in other policy areas, and whether there are systematic differences of this kind between domestic and international commitments and across different policy areas.

\section{Theory}

If each country were equally affected by the free-rider problem associated with the production of global public goods, countries around the globe would, in the absence of other influences, be equally reluctant to contribute to the provision of such goods. Table 1 suggests that this is not the case. Moreover, in climate change policy, smaller countries whose emission reductions can contribute only minimally to solving the overall problem, should have a strong motivation to wait and let the big countries move ahead first. A simple test questions this assumption. In

23. See, for example, Ward 2008; Neumayer 2002; and Li and Reuveny 2006.

24. See, for example, Congleton 1992; and Midlarsky 1998. 
the data set we use for this article (see below), the correlation between country size - in terms of population or gross domestic product (GDP) — and GHG emission growth rates, as well as other indicators for countries' performance in climate change mitigation efforts, is close to zero. That is, on average, smaller countries are neither less nor more cooperative.

A likely explanation for the cross-country variance we observed is that institutions matter. Political institutions differ along many dimensions. We are interested in the effects of democracy. Democracy is arguably the most fundamental characteristic when comparing national political institutions globally. ${ }^{25}$ Our basic argument is that democracy has a positive effect on the demand for and supply of public goods, including global public goods such as climate change mitigation, and that this effect is likely to be stronger with respect to policy output than policy outcome. We arrive at this argument by first outlining the fundamental reasons for the expected positive democracy effect and then addressing two caveats.

Olson, McGuire and Olson, and other authors have argued that nondemocratic polities tend to underprovide public goods. ${ }^{26}$ They are usually governed by small elites who seek to increase their personal wealth at the expense of the population. Hence they have little interest in foregoing private benefits, such as spending tax income on personal consumption or to buy loyalty from cronies, in order to invest in greater amounts of public goods-such as higher levels of environmental quality - that would benefit large parts of the population. That is, public goods are underprovided if opportunity costs associated with public goods provision are concentrated on a small elite, whereas the benefits are widely dispersed. In democracies, provision levels of public goods are influenced much more strongly by the preferences of the median voter or, in a more open formulation, prevailing interests among the electorate. The median voter (or the individual member of the electorate) in democracies incurs smaller opportunity costs from more environmental protection, relative to the median member of the ruling elite in a nondemocracy. Collective action theory tells us that the former cost-benefit distribution is more conducive to public goods provision than the latter. ${ }^{27}$

An extension by Bueno de Mesquita and colleagues of the aforementioned argument focuses on how institutions influence the selection of political leaders and their incentives to provide public goods. ${ }^{28}$ They claim that the extent to which governments provide public goods relative to private ones is determined by the size of the "selectorate" (those who affect the selection of and receive benefits from the leaders) and the size of the winning coalition (the subset of the selectorate that is needed to bring or keep leaders in office). In nondemocracies, the

25. See Przeworski 2004; and Munck and Verkuilen 2002. Obviously, climate change is a global problem that requires cooperation by all countries worldwide, at the very least in terms relative to their GHG emissions. This justifies a global perspective.

26. See Olson 1993; McGuire and Olson 1996.

27. See Stigler 1971; and Olson 1968.

28. Bueno de Mesquita et al. 2003. See also Bernauer and Koubi 2009. 
winning coalition is usually small relative to the selectorate. In such systems, leaders thus need to deliver a relatively large amount of private goods to a small number of essential supporters to be able to remain in power. In contrast, in democracies the winning coalition is large relative to the selectorate. Political leaders in democratic systems do not have sufficient resources to reward their supporters with large amounts of private goods. Moreover, loyalty to the incumbent tends to be weaker in democracies than in autocracies (that is, the probability of defection from winning coalitions is higher in democracies). Weaker loyalty of supporters forces democratic political leaders to deliver policies that provide relatively large amounts of public goods if they wish to survive politically. In autocracies, loyalty of elite members to incumbents is usually higher, and this motivates autocratic leaders to deliver more private goods to the small elite that keeps them in power.

This optimism (at the theoretical level) about superior performance of democracies in terms of public goods provision has encountered criticism of various sorts. We address what we regard as the two most important caveats and conclude that only the second of these caveats requires a modification of the basic hypothesis. This caveat leads us to distinguish democracy effects on policy outputs from effects on policy outcomes.

\section{Caveat 1: The Demand Side}

The democracy effect argument presented above has both demand- and supplyside components. As to the supply side, it seems reasonable to assume that, at any given level of public demand, democratic leaders are likely to experience greater incentives than autocratic leaders to satisfy this demand. The demand side is more problematic. Extant research has not systematically dealt with the possibility that the median voter does not prefer more environmental quality, or that parochial interest groups dominate the political process.

It is quite intuitive to assume that the median voter in a democracy will usually be more enthusiastic about public goods provision than the median elite member in a nondemocracy. Examples are public schools, public infrastructure (for example, water supply and sanitation, hospitals, electricity, telecommunications), or clean air. We cannot assume automatically, however, that demand for any type of public good is greater in democracies than in autocracies. The existing literature does not offer systematic empirical evidence on this issue..$^{29}$ But we argue that there are several reasons why the median voter in democracies will, on average, be "greener" than the median elite member in nondemocracies.

29. See Diekmann and Franzen 1999; and Franzen and Meyer 2004. All large-scale surveys, such as the International Social Survey Program, focus primarily on democratic countries and do not allow us to determine whether, ceteris paribus, individual environmental preferences are also shaped by the political system. 
Critics may object that the median elite member in a nondemocracy tends to be wealthier and better educated than the median voter in a democracy and, assuming that environmental quality is a "normal" good, ${ }^{30}$ thus demands more environmental quality. ${ }^{31}$ At least four arguments cut against this idea. First, democracies are on average richer than autocracies. ${ }^{32}$ It is also well established in the literature that political participation of richer voters in democracies is higher. Consequently, the de facto median voter in democracies may not be poorer than the median elite member in nondemocracies. Second, the median elite member in an autocracy will usually have more opportunities than the average member of the country's population to shield that elite member from negative consequences that may arise from the underprovision of public goods. For example, that elite member can move to a less polluted place within the country (or abroad). Wealthy persons in democracies can, of course, do the same. But this does not undermine demand for public goods provision to the same extent it does in nondemocracies, where the median elite member has more political influence. Third, as noted above, opportunity costs of environmental policies are likely to be higher for the median elite member in a nondemocracy than the median voter in a democracy. The anticipated net benefits of environmental policy will thus be smaller for the median elite member in a nondemocracy. That is, even if the median elite member in an autocracy were greener than the democratic median voter, higher opportunity costs are more likely to lead that member to negative expected net benefits of more environmental protection. Fourth, greater freedom to engage in research, communicate, exchange new evidence on environmental risks, and travel to and obtain information from other countries is likely to make the public in democratic countries more aware of environmental problems and possibilities for their mitigation. ${ }^{33}$ This applies particularly to more complex, less visible, and less local risks (for example, climate change).

Criticism of the democracy-environment hypothesis has also focused on the role of interest groups, arguing that the preferences of the median voter may matter less in the policymaking process than the preferences of influential interest groups. Some critics have claimed that in advanced democracies ever greater interest group pluralism may reduce the provision of public goods. ${ }^{34}$ Politicians are forced to adopt more and more policies that cater to narrowly defined short-term interests of particular groups instead of longer-term interests of the public as a whole.

30. See, for example, Cole and Neumayer 2005.

31. At least some forms of environmental degradation are characterized by an environmental Kuznets curve (EKC) (see Grossman and Krueger 1995). Pollution first increases with income as people favor increased economic output over improvement of environmental quality. Once income has reached a higher level and basic material needs have been met, the willingness to invest more in "postmaterial" goods, such as environmental quality, increases.

32. Correlations between various measures of income and democracy are usually in the order of 0.4 to 0.6 .

33. See also Payne 1995.

34. See, for example, Olson 1982; and Midlarsky 1998. 
Increasingly strong competition among interest groups may also make it harder to adopt policies that depart substantively from the status quo (gridlock problem). While it is possible that more mature democracies are characterized by more interest group activity, and increasing activity of this nature increases the likelihood of gridlock, we are not aware of any systematic studies that demonstrate such effects for a large sample of countries in environmental policy.

Critics of the democracy-environment hypothesis have also referred to the Olsonian notion that concentrated interests are easier to organize than diffuse interests. To the extent that the costs of slowing down or halting environmental degradation fall primarily on business, whereas the population as a whole benefits, we should expect that business holds less green preferences than the median voter, and that business is able to organize more effectively. Since virtually all highly democratic countries are advanced market economies where the private sector plays the key role in innovation and economic growth, the combination of economic and political freedom may favor business interests over the interests of the median voter and may hence slow progress in environmental policy. While the literature on interest group activity in economic policymaking offers some evidence for greater influence of business relative to other interests, ${ }^{35}$ the environmental policy literature provides many examples where business interests have been overwhelmed by environmental interests. ${ }^{36}$ In some cases, international cooperation-for example, the agreements to protect the stratospheric ozone layer-was even facilitated by "green and greedy" coalitions among business stakeholders and environmental interests. ${ }^{37}$

Rather than creating gridlock, increasing interest group pluralism may thus weaken the pro-business bias of interest group politics and hence promote green interests. If, for instance, greater pluralism in advanced democracies decreases the effectiveness of behind-the-doors lobbying by industry (whose preferences are presumably less green), environmental interest groups may in fact gain greater influence because industry has traditionally been more influential in behind-the-doors lobbying. Beck, Aerni, and others have argued that in mature democracies, interest groups have in recent years been competing harder and harder for the attention of the public, and that public trust has become a key political resource in this process. ${ }^{38}$ Surveys have shown that in many countries the general public has more confidence in the information provided by nongovernmental organizations (NGOs) than the information provided by business. ${ }^{39}$ In many cases, this loss of confidence in business as a stakeholder has put policymakers under intense pressure to shield constituencies from an ever larger range of risks, including environmental risks, often at the expense of business interests. In addition, more pluralistic societies tend to exhibit lower levels of corruption. Corruption is one of the mecha-

35. See, for example, Dryzek 1987.

36. See, for example, Vogel 2005; Bernauer and Caduff 2004; and Bernauer 2003.

37. See, for example, Oye and Maxwell 1994.

38. See Beck 1986; and Aerni 2005.

39. Aerni 2005. 
nisms through which business interests can obtain political influence, and it directs government resources to the production of private goods. In other words, if democracy promotes interest group pluralism, such pluralism may well lead to more rather than less provision of public goods.

In summary, both demand and supply arguments point, on balance, toward a net democracy effect that is positive. Demand for environmental public goods provision is likely to be at least equally strong, and probably stronger, in democracies than in nondemocracies. At any given level of public demand for public goods provision larger than the status quo (or greater than zero), democratic systems are more likely to supply the desired public goods.

\section{Caveat 2: National Versus Global Public Goods, Policy Output Versus Policy Outcome}

A primary characteristic of climate change mitigation is that it is a global public good, that is, the geographic scope of the problem is not congruent with national territories. Since democratic processes operate primarily within the domestic sphere, constituencies and politicians may be less interested in resolving international or global issues relative to domestic problems. ${ }^{40}$ Consequently, we may find that democracy is helpful in dealing with local or national public goods problems, such as local air or water pollution, but not necessarily with complex global problems. However, this argument does not invalidate the democracy-environment hypothesis. Even if the global public goods nature of climate change mitigation weakens the democracy effect, this weakening should be viewed as relative to other public goods problems (notably local or national public goods). There is no reason to assume that any such weakening should be systematically stronger with respect to democracies than nondemocracies.

However, this caveat motivates us to pay more attention to the distinction between policy output and policy outcome. The problem of human-induced climate change has been on the global policy agenda for only about fifteen years, but designing and implementing mitigation policies is complex, costly, and time-consuming. We should thus expect that democracy effects vary across policy output and policy outcome, with democracy having a weaker effect on policy outcomes. This possibility was noted by Neumayer several years ago with respect to other environmental degradation issues but has been largely ignored in subsequent research. ${ }^{41}$

The principal reason to study policy output and outcomes side by side and to expect a weaker democracy effect on outcomes is that the causal chain from environmental risks to public perceptions of such risks, to public demand for risk mitigation, and to policy output is shorter than the one leading from risk via policy output to policy outcome. Because of that, outcomes are, to the extent policies are 
effective, influenced by policy output, but also by a range of other factors, such as properties of the resource in question, mitigation costs, efficiency of implementing agencies, and so on. Whereas policy outputs are largely under the control of policymakers, policy outcomes may be affected also by factors that are outside of their control. Under conditions of complete information, policymakers will correctly determine the level of environmental protection that provides a net benefit (benefit from risk mitigation minus mitigation costs, including implementation costs) and meets median voter or prevailing interest group demands. They will also anticipate potential implementation problems and design effective monitoring and enforcement mechanisms to that end. But more often than not, such assumptions are violated in the real world. In fact, a common observation in many studies on environmental policy is that policymakers often respond quite well to public demands for more environmental protection, but tend to discount implementation problems, hoping that voters will not be able to identify these problems within a short-enough time-period to be able to punish policymakers.

In sum, the theoretical reasoning in this section produces two hypotheses that will be tested in the remainder of this article.

H1: More democratic countries exhibit stronger political commitment to climate change mitigation.

H2: More democratic countries contribute more to climate change mitigation in terms of emission reduction. However, this positive democracy effect is weaker than the democracy effect on policy output.

\section{Empirical Design}

\section{Approach}

Focusing on climate change mitigation subjects the democracy-environment hypothesis to a particularly hard test. Because the focus is on national contributions to a global public good associated with substantial scientific uncertainty, a strong freeriding problem, and rather high mitigation costs, any significant, positive effect of democracy will be more convincing than in the case of more local, more visible, and scientifically less-contested environmental degradation issues (for example, local air or water pollution).

The existing literature has produced contradictory results for the democracy effect in climate change mitigation policy. Congleton reports that democracies have higher levels of methane and CFC emissions per capita (his sample included 118 countries in 1989). ${ }^{42}$ Midlarsky finds that more democratic countries have higher per capita carbon dioxide $\left(\mathrm{CO}_{2}\right)$ emissions (his sample included ninety-eight coun- 
tries in 1990). ${ }^{43}$ Gleditsch and Sverdrup find that democracy reduces $\mathrm{CO}_{2}$ emissions per capita (their sample included 108 countries in 1990). ${ }^{44} \mathrm{Li}$ and Reuveny obtain mixed results for $\mathrm{CO}_{2}$ emissions per capita (their sample included 143 countries from 1961 to 1997): while the effect of a continuous indicator for democracy (Polity IV) is negative and significant, it is positive but not significant for a dichotomous indicator of democracy, and positive and significant for a dichotomous indicator of autocracy. ${ }^{45}$ As to policy output, a recent study by von Stein finds that democracy tends to have a positive effect on formal participation in global climate change policy (the sample included 140 countries from 1992 to 2005). ${ }^{46}$

The empirical results for the democracy-climate policy hypothesis we just discussed are likely to differ due to differences in sampling (number of countries, cross-sectional analysis for individual years or time-periods versus panel data analysis) and different definitions of the dependent variable (emission levels versus trends, policy outcomes versus policy output). We opt for a more comprehensive approach, focusing on 185 countries since 1990, when the climate change issue moved onto the global policy agenda, and examining policy output and outcome side by side. The analysis is cross-sectional because year-to-year changes on our dependent variables and the main independent variable (democracy) are much smaller than crosssectional variation. The data analysis relies on ordinary least squares (OLS) with robust standard errors (Huber-White estimator).

The dependent variable measures levels of public goods provision in climate change mitigation across countries. It is defined in four forms: in terms of indices for policy output and policy outcome, as well as indicators for emission levels and emission trends. The first index captures policy output; the second index and the two emissions indicators measure policy outcomes. We use three measures for policy outcomes to distinguish emission levels and emission trends because there is disagreement in the literature over which concept is more appropriate. Murdoch and Sandler and some other authors argue that pollution levels may not be appropriate when examining the effect of democracy on policy outcomes, and that one should study trends (or changes); that is, whether democracy contributes to emission reductions ${ }^{47}$ We agree that the latter approach is better connected to the basic proposition: we do not argue that democracies are "cleaner" at any given point in time; rather, we claim that democracies make a bigger effort to improve their environmental behavior.

Our principal empirical models explain public goods provision as a function of democracy, controlling for climate change risk exposure, income, mitigation costs, trade, and other factors. The robustness of findings is assessed in a variety of ways.

43. Midlarsky 1998.

44. Gleditsch and Sverdrup 2003.

45. Li and Reuveny 2006.

46. von Stein 2008a.

47. Murdoch and Sandler 1997. Neumayer 2002, 144, points to this problem in studies by Midlarsky 1998; Torras and Boyce 1998; and Barrett and Graddy 2000. 
We start by excluding the richest countries from the sample because most of the richest countries are highly democratic. Their inclusion might thus bias the results. We also examine the robustness of findings by using alternative indicators for democracy, climate change risk exposure, income, mitigation costs, and trade, and by running the models for the four component indicators of the policy output index separately. In addition, we add a wide range of other control variables. We then reassess the basic results by implementing the models for a climate change cooperation index from another source-that index includes emission levels, emission trends, and a policy component. The final part examines the effect of democracy on GHG emissions by particular economic sectors, notably electricity and heat production, and transportation.

\section{Variables}

Table 2 offers an overview of variables and data sources. Policy OUTPUT measures the extent of political, legal, and administrative commitments to the UN-based climate change mitigation process. This index is based on Bättig, Brander, and Imboden $^{48}$ and includes the following indicators: (1) the UN Framework Convention on Climate Change (UNFCCC) indicator, which is composed of two equally weighted indicators measuring whether the country has ratified the UNFCCC (yes $=1$, no $=0$ ) and how fast it has done so (declining scale from 1992 through 1997); (2) the Kyoto indicator, which is composed of two equally weighted indicators measuring whether the country has ratified the Kyoto Protocol (yes $=1$, no $=0$ ) and how fast it has done so (declining scale from 1998 through 2005); (3) the reporting indicator, which is composed of two equally weighted indicators measuring whether the country has submitted the latest national climate report (yes $=1$, no $=0$ ) and whether it has done so in time; and (4) the funding indicator, which measures how often a country has made its financial contributions to the UNFCCC secretariat in time between 1996 and 2005 (linear scale according to the number of contributions in time). The values of the four components are added with equal weight since there is no compelling argument for why one or the other component should be more important. The values of the policy output index are standardized on a 0 to 1 scale. Higher values indicate more cooperative behavior.

Policy outcomes are measured in three ways. The policy OUTCOME index assesses primarily emission trends. It is composed of two elements: 1990 levels of $\mathrm{CO}_{2}$ emissions per capita in relation to GDP per capita; and the trend of $\mathrm{CO}_{2}$ emissions per capita in relation to GDP per capita between 1990 and 2002. The latter element of the index captures the trend of emissions compared to a quadratic function fitted into the emissions of thirteen EU countries in the 1870 to 2002 period. That is, it uses a fitted environmental Kuznets curve as a benchmark and measures

48. Bättig, Brander, and Imboden 2008. 
TABLE 2. Variables in the principal models

\begin{tabular}{|c|c|c|}
\hline Variables & Definition & Source \\
\hline OUTPUT & $\begin{array}{l}\text { Index of cooperative behavior in climate } \\
\text { change policy, defined in policy output } \\
\text { terms; scale: } 0 \ldots 1 \text {, higher values } \\
\text { indicate more cooperative behavior; } \\
\text { 1990-2005. }\end{array}$ & $\begin{array}{l}\text { Based on Bättig, } \\
\text { Brander, and } \\
\text { Imboden } 2008\end{array}$ \\
\hline OUTCOME & $\begin{array}{l}\text { Index of cooperative behavior in climate } \\
\text { change policy, defined in emissions } \\
\text { related terms; scale: } 0 \ldots 1 \text {, higher } \\
\text { values indicate more cooperative } \\
\text { behavior; } 1990-2003 \text {. }\end{array}$ & $\begin{array}{l}\text { Based on Bättig, } \\
\text { Brander, and } \\
\text { Imboden } 2008\end{array}$ \\
\hline EMISSLEVEL & $\begin{array}{l}\text { Natural log of } \mathrm{CO}_{2} \text { emissions per capita; } \\
\text { 1990-2004 averages; transformed to } \\
0 . .1 \text { scale and inverted; higher values } \\
\text { indicate more cooperative behavior. }\end{array}$ & Based on CAIT 2008 \\
\hline EMISSTREND & $\begin{array}{l}\text { Average annual growth rate of } \mathrm{CO}_{2} \\
\text { emissions per capita; } 1990-2004 \\
\text { averages; transformed to } 0 . .1 \text { scale } \\
\text { and inverted; higher values indicate } \\
\text { more cooperative behavior. }\end{array}$ & Based on CAIT 2008 \\
\hline DEMOCRACY & $\begin{array}{l}\text { Political rights index by Freedom House; } \\
\text { 1990-2005 averages; scale of original } \\
\text { data inverted, 1...7, higher values } \\
\text { indicate more democracy. }\end{array}$ & Freedom House 2006 \\
\hline CCI & $\begin{array}{l}\text { Climate Change Index; index of climate } \\
\text { change risk exposure; scale: } 0 \ldots 1 \text {, } \\
\text { higher values indicate greater risk for } \\
\text { the respective country. }\end{array}$ & $\begin{array}{l}\text { Bättig, Wild, and } \\
\text { Imboden } 2007\end{array}$ \\
\hline INCOME, INCOMESQUARE & $\begin{array}{l}\text { GDP per capita in PPP (1990 international } \\
\text { Geary-Khamis dollars); natural log of } \\
\text { averages for 1990-2003 or most recent } \\
\text { year for which data was available. } \\
\text { INCOME }=\ln (\text { GDP per capita }) \\
\text { INCOMESQUARE }=(\ln (\text { GDP per capita }))^{2}\end{array}$ & Maddison 2007 \\
\hline GDPGROWTH & Average annual growth of GDP per capita. & $\begin{array}{l}\text { World Bank 2006; } \\
\text { Maddison } 2007\end{array}$ \\
\hline $\mathrm{CO}_{2} \mathrm{CAP} 1990$ & $\mathrm{CO}_{2}$ emissions per capita in 1990 . & CAIT 2008 \\
\hline OILGASCOAL & $\begin{array}{l}\text { Sum of oil, gas and coal production per } \\
\text { capita (all in millions of tons of oil } \\
\text { equivalents); 1990-2005 (or most recent } \\
\text { year) averages. }\end{array}$ & $\begin{array}{l}\text { Based on data from } \\
\text { British Petroleum } \\
2007\end{array}$ \\
\hline TRADEOPEN & $\begin{array}{l}\text { Trade openness (imports plus exports } \\
\text { divided by GDP), 1990-2000. }\end{array}$ & Gleditsch 2006 \\
\hline
\end{tabular}

Note: the dependent variables are shown in the shaded area of the table.

how well a country performs in relation to this benchmark. Relating emission trends and levels to income offers an indication of how well countries are coping with the challenge of growing economically without excessively damaging the natural environment. The values of the index, whose construction is described in greater 
detail in Bättig and colleagues are standardized on a 0 to 1 scale. ${ }^{49}$ Higher values indicate more cooperative behavior. In addition, we use two indicators whose definition is more simple and straightforward: $\mathrm{CO}_{2}$ emissions per capita (EMISSLEVEL), and growth of $\mathrm{CO}_{2}$ emissions per capita (EMISSTREND). For both indicators we use 1990-2004 averages. To facilitate comparison with the policy output and outcome indices, we invert the scale of EMISSLEVEL and EMISSTREND, so that higher values indicate lower emissions and thus greater contributions to the global public good. We standardize the values to a 0 to 1 scale. We would like to emphasize at this point that the three policy outcome variables measure emission behavior in the broadest possible manner; they do not measure compliance with Kyoto commitments or the effectiveness of such commitments.

DEMOCRACY is measured with the Freedom House political rights index. ${ }^{50} \mathrm{We}$ use this index primarily because it is available for a larger number of countries and more recent years than the Polity IV index ${ }^{51}$ and other indices for democracy. We invert the original scale, making 1 the least and 7 the most democratic score, and use 1990-2005 averages.

All models include a set of control variables. The Climate Change Index (CCI) is based on predictions of future annual and seasonal temperature and precipitation. It captures the degree of future climate change relative to today's natural variability and is calculated on the basis of three global climate model (GCM) simulations of the twenty-first century under the IPCC emission scenarios A2 and B2. While this indicator does not measure climate impacts (for example, in terms of how many percentages climate change could reduce GDP within particular timeframes) it provides a reasonably clear picture of how strong climatic change in individual countries is likely to be. ${ }^{52}$ Higher values on a 0 to 1 scale indicate higher risk exposure of a country. We include this control variable because most theories of international environmental cooperation argue that risk-exposure plays a central role in accounting for why countries respond differently to any given category of international problems. ${ }^{53}$ We expect the index to have a positive effect on cooperative behavior.

INCOME is measured as the natural logarithm of GDP per capita. ${ }^{54}$ We use averages for 1990-2002 (or the most recent year for which data is available). We also include the squared value of this indicator to account for the possibility of an environmental Kuznets curve. ${ }^{55}$ We expect a positive, linear effect of income

49. Ibid.

50. Freedom House 2006.

51. Marshall and Jaggers 2007.

52. For a more detailed description, see Bättig, Wild, and Imboden 2007.

53. See, for example, Sprinz and Vaahtoranta 1994; and Social Learning Group 2001.

54. PPP, 1990 U.S. dollars.

55. A common assumption in the environmental economics literature is that pollution first grows with income and, at some point that may vary across pollutants and countries, starts to decline. If this inverted U-shape - the so-called environmental Kuznets curve (EKC) —effect exists, the income variable should have a negative and the squared income variable a positive coefficient. 
on policy output. Except for the models including outcome as the dependent variable, the models also include economic growth (GDPGROWTH). For models including emission levels and trends as dependent variables we expect nonlinear effects of GDP growth. At lower levels of income, growth is likely to increase emissions. At higher levels of income, it is likely to be associated with nonincreasing or decreasing emissions. All models include a trade openness (TRADEOPEN) variable (exports plus imports divided by GDP). The existing literature ${ }^{56}$ is divided on whether trade effects are positive, negative, or insignificant. The main reason for uncertainty about the direction and size of trade effects is that trade may have effects on economic structure (composition), economic output (scale), and income ${ }^{57}$; it is empirically open which of the three effects dominates or whether they offset each other.

We include a variable that proxies for mitigation costs. There is no agreement in the literature on how to estimate mitigation costs. ${ }^{58} \mathrm{We}$ opt for a simple indicator$\mathrm{CO}_{2}$ emissions per capita in $1990\left(\mathrm{CO}_{2} \mathrm{CAP} 1990\right)$ - but assess the impact of alternative measures in our robustness checks. We acknowledge that the effect of the chosen indicator may cut both ways. Countries with higher per capita emissions may be less energy-efficient and may thus find it easier to reduce emissions, at least for some time. Conversely, to the extent that international notions of fairness demand that in the long term such countries have to bring their emissions down to some uniform per capita level (many proposals refer to this as "carbon justice" and often refer to two to five tons of $\mathrm{CO}_{2}$ per capita and year), they may be less willing to cooperate. We use this indicator in all models except those for the policy outcome index- $-\mathrm{CO}_{2}$ emissions per capita are used in the construction of that index. Instead, we use fossil fuel production in those models, assuming that producers of fossil fuels (oil, gas, coal) will, for economic reasons, be less interested in contributing to climate change mitigation. This indicator is defined as total fossil fuel production (oil, coal, gas, all in oil equivalents) per capita (OILGASCOAL). ${ }^{59}$

The policy output index is included as a control variable in the models for emission levels and trends, assuming that politically more committed countries are performing better in political outcome terms as well.

\section{Results}

We start by estimating the effect of democracy on four indicators for national contributions to global climate change mitigation: (1) policy OUTPUT; (2) policy outcome; (3) emission levels (EmissLevel); and (4) changes in emission levels

56. See, for example, Cole and Neumayer 2005.

57. Antweiler, Copeland, and Taylor 2001.

58. See, for example, Stern 2007.

59. We do not use fossil fuel consumption because the available data is less reliable and rather incomplete, and because GHG emissions are directly related to fossil fuel consumption. 
(EMISSTREND). All dependent variables are scaled from 0 to 1 , with higher values indicating larger contributions to the global public good. ${ }^{60}$ Table 3 shows the estimates.

TABLE 3. Effects of democracy

\begin{tabular}{|c|c|c|c|c|}
\hline Variables & $\begin{array}{l}\text { Model } 1 \\
\text { Output }\end{array}$ & $\begin{array}{l}\text { Model } 2 \\
\text { outcome }\end{array}$ & $\begin{array}{c}\text { Model } 3 \\
\text { EMISSLEVEL }\end{array}$ & $\begin{array}{c}\text { Model } 4 \\
\text { EMISSTREND }\end{array}$ \\
\hline DEMOCRACY & $\begin{array}{l}0.0312 * * * \\
(0.0088)\end{array}$ & $\begin{array}{c}-0.0227 * * * \\
(0.0087)\end{array}$ & $\begin{array}{l}0.0095 * * \\
(0.0038)\end{array}$ & $\begin{array}{c}0.0025 \\
(0.0059)\end{array}$ \\
\hline $\mathrm{CCI}$ & $\begin{array}{c}-0.1431 \\
(0.0940)\end{array}$ & $\begin{array}{c}0.1192 \\
(0.1157)\end{array}$ & $\begin{array}{c}-0.0063 \\
(0.0401)\end{array}$ & $\begin{array}{c}-0.1774 * * * \\
(0.0521)\end{array}$ \\
\hline INCOME & $\begin{array}{l}0.0599 * * * \\
(0.0191)\end{array}$ & & $\begin{array}{c}-0.7305^{* * *} \\
(0.0848)\end{array}$ & $\begin{array}{r}-0.1189 \\
(0.1260)\end{array}$ \\
\hline INCOME $^{2}$ & & & $\begin{array}{l}0.0368 * * * \\
(0.0053)\end{array}$ & $\begin{array}{c}0.0053 \\
(0.0075)\end{array}$ \\
\hline GDPGROWTH & $\begin{array}{r}-0.0068 \\
(0.0053)\end{array}$ & & $\begin{array}{l}0.0040 * * \\
(0.0018)\end{array}$ & $\begin{array}{r}-0.0144 * \\
(0.0074)\end{array}$ \\
\hline $\mathrm{CO}_{2} \mathrm{CAP} 1990$ & $\begin{array}{r}-0.0050 * \\
(0.0027)\end{array}$ & & $\begin{array}{c}-0.0142^{* * * *} \\
(0.0021)\end{array}$ & $\begin{array}{l}0.0072 * * * \\
(0.0016)\end{array}$ \\
\hline OILGASCOAL & & $\begin{array}{c}-442.0084 * * * \\
(111.0305)\end{array}$ & & \\
\hline TRADEOPEN & $\begin{array}{c}-0.0436 * * \\
(0.0201)\end{array}$ & $\begin{array}{c}-0.1115^{* *} \\
(0.0524)\end{array}$ & $\begin{array}{c}0.0121 \\
(0.0168)\end{array}$ & $\begin{array}{c}0.0070 \\
(0.0153)\end{array}$ \\
\hline OUTPUT & & $\begin{array}{c}0.1378 \\
(0.0883)\end{array}$ & $\begin{array}{c}0.0483 \\
(0.0417)\end{array}$ & $\begin{array}{c}-0.0678 \\
(0.0629)\end{array}$ \\
\hline Constant & $\begin{array}{c}0.1211 \\
(0.1337)\end{array}$ & $\begin{array}{l}0.6017 * * * \\
(0.0888)\end{array}$ & $\begin{array}{l}3.8572 * * * \\
(0.3437)\end{array}$ & $\begin{array}{l}1.2871 * * \\
(0.5322)\end{array}$ \\
\hline Observations & 172 & 182 & 172 & 171 \\
\hline$R$-squared & 0.325 & 0.207 & 0.881 & 0.288 \\
\hline
\end{tabular}

Notes: Robust standard errors in parentheses. * significant at $10 \%$; ** significant at $5 \%$; *** significant at $1 \%$.

Democracy has a positive and significant effect on policy output and on the emission level variable. These effects are substantial: a one-point increase in democracy (around 17 percent on the $1 . .7$ scale) produces a 3.2 percent increase in policy output and a 1 percent increase in policy outcome defined in terms of emission levels. If democracy levels change from those of China (minimum) to those of Canada (maximum), this increases policy output by 19 percent and improves emission levels by 6 percent. These results support hypotheses (1) and (2). Hypothesis (1) (as tested in Model 1, Table 3) claims that more democratic countries exhibit greater political commitment to climate change mitigation. Hypothesis (2)

60. The data set, Stata do-files, and a paper presenting additional empirical results (for example, robustness checks) are available from the authors. 
(as tested in Model 3, Table 3) holds that more democratic countries perform better in reducing their emissions, though this effect is likely to be weaker. Indeed, the democracy coefficient in Model 3 is significantly smaller than in Model 1.

The effects of democracy on the policy outcome index and emission trends (Models 2 and 4, Table 3) cut against hypothesis (2). ${ }^{61}$ The effect of democracy on the former is negative and significant, the effect on the latter is positive but insignificant; that is, the results shown in Table 3 support hypothesis (1) but offer only very limited support for hypothesis (2).

The coefficients for the climate change index show that risk exposure does not motivate countries to contribute to the global public good. In the model for emission trends, the effect is even negative and significant. We interpret this finding in the sense that available scientific information on climate change has not (yet?) spurred sufficient public demand for risk mitigation, that the free-rider problem reduces demand for and supply of risk mitigation measures, or both.

As expected, the income effect on policy output is positive and significant. ${ }^{62}$ We also implemented the model with income divided by the Gini index to approximate the income of the median voter. The results (not shown here) are very similar. The environmental Kuznets curve effect is strong in the models for emission levels and follows the expected pattern: emissions increase with income, and at high levels of income start to decrease. This effect is similar for emission trends, but much weaker. Economic growth has a heterogeneous effect. It has no significant effect on policy output, a positive effect in terms of lower emission levels, but an adverse effect on emission trends. The expected Kuznets curve effect for GDP growth does not show up in our data. We cross-checked this result using an interaction term for income and growth. The results (not shown here) are very similar. Per capita $\mathrm{CO}_{2}$ emission levels in 1990 have a significant, negative effect on policy output and the emission level variable, but a significant, positive effect on the emission trend variable. Production of fossil fuels has the expected negative effect on public goods provision. The same effect shows up when we use this variable in the other models in lieu of $1990 \mathrm{CO}_{2}$ emissions per capita. The negative effect of trade openness on policy output supports the regulatory chill over the trading-up hypothesis. ${ }^{63}$ Countries that are more open to international trade are more reluctant to commit to climate change mitigation.

Our data can also be used to test whether democracies find it easier or harder to bring their self-selected political commitment levels in line with their environ-

61. The overall properties of Model 2 are somewhat problematic because fossil fuel production (whose distribution is very skewed) is by far the strongest determinant.

62. Multicolinearity problems in the models reported in Table 3 are minor. The highest bivariate correlations among explanatory variables are those between income and democracy (0.59) and income and per capita $\mathrm{CO}_{2}$ levels in 1990 (0.62). The results are consistent across the full sample (all countries in our data set) and a reduced sample that excluded the richest 10 percent of the countries in the data set.

63. Vogel 1995. 
mental behavior. To start with, the effect of the policy output variable in the emission level and trend models is positive in most of our models, but statistically significant in only one of them. This suggests that, for all countries in our sample, "words and deeds" are not strongly related. What role does democracy play in this context? To assess this effect, we constructed a new dependent variable. This variable is defined as the policy outcome (the sum of the EMISSLEVEL and EMISSTREND variable, standardized to a 0 to 1 scale) minus the policy output variable. -1 on this scale identifies countries that are investing far more in words than in deeds, +1 identifies countries at the opposite end. When we implement the exact same model as for EMISSLEVEL for this new dependent variable, we find that both democracy and income have a significant negative effect (results not shown here). That is, rich and democratic countries are particularly prone to perform better at the political commitment level than in terms of cutting their emissions.

Our results for the policy output index correspond to findings by von Stein, ${ }^{64}$ which to our knowledge is the most sophisticated large-N study focusing on policy output in the climate change area. ${ }^{65}$ The results for emissions-related behavior are helpful in addressing contradictory findings by Gleditsch and Sverdrup, Li and Reuveny, Congleton, and Midlarsky. ${ }^{66}$ As noted above, focusing on emission trends rather than levels may offer a more appropriate test of the democracy-environment hypothesis. We should expect that, ever since climate change policy emerged on the international agenda in the mid- to late 1980s, democracies have been doing a better job in dealing with the problem, irrespective of whether their emission levels were higher or not at the outset of the process (we control for this possibility by including $1990 \mathrm{CO}_{2}$ emissions per capita). The democracy coefficient in the model for the policy outcome index turns out to be negative and significant, in the model for emission trends it is positive but insignificant. The overall conclusion is that we should be very cautious and perhaps even skeptical in interpreting the positive democracy effect on emission levels as confirmation of the democracyenvironment hypothesis.

How robust are these results? For a start, we examined whether excluding the richest 10 percent of the sample (most of these countries are highly democratic) changes the results. It does not. We then explored whether outliers and/or skewed distributions of variables affected the results, but we did not identify significant problems of this kind. For example, we examined the effects of dropping particular countries that appeared as outliers. The results are robust to excluding Iceland, Suriname, and Andorra. These three countries are outliers on the policy output,

64. von Stein 2008a.

65. The income indicators are not used in the models with ouTCOME as the dependent variable because the latter's construction includes income. The squared income indicator is not used in models with OUTPUT as the dependent variable because there is no theoretical or empirical argument for assuming a non-linear effect.

66. See Gleditsch and Sverdrup 2003; Li and Reuveny 2006; Congleton 1992; and Midlarsky 1998. 
democracy, and climate risk variables. Iceland scores very high on democracy and policy output, but very low on climate risk. Suriname scores very high on climate risk and very low on policy output. Andorra scores very high on democracy, but very low on policy output. We then cross-examined the results in five more ways: by using six alternative indicators for democracy; by separately estimating the effects of democracy on the four component indicators of the policy output index; by using alternative indicators for climate risk, income, mitigation costs, and trade openness; by adding additional control variables; and by defining an overall climate policy performance index, implementing the explanatory model for this dependent variable and a climate policy performance measure provided by another source (Germanwatch), ${ }^{67}$ and comparing the results. None of these robustness checks changed the conclusions in important ways.

We focused on the last robustness check in some more detail. ${ }^{68}$ We replaced our indicators for the dependent variable with the hitherto most widely used index for national performance in climate change policy, the Climate Change Performance Index (CCPI) by Germanwatch. ${ }^{69}$ This index combines data for emission levels (30 percent weight), emission trends (50 percent weight), and climate policy (20 percent weight). Its 2008 version is available for fifty-six countries (compared to the more than 180 countries in our data set). We standardized the CCPI to the same scale $(0 \ldots 1,1$ indicating strongest performance) used for all definitions of the dependent variable in Table 3 (GWSCORE). For purposes of comparison, we constructed a similar index based on our own data set, with the same weights of the three components (OUTPUT $=20$ percent, EMISSTREND $=50$ percent, EMISSLEVEL $=30$ percent, CPPER FORM).

Table 4 shows that the results for the democracy effect are positive and significant for both overall indices of climate policy performance. The caveat is, however, that such overall measures obfuscate important differences between policy output and policy outcome, as shown in Table 3. We also replaced our policy output index with the policy component of the Germanwatch index. The results (not shown here) for the democracy effect are the same as for the models including our policy output index.

As shown above, democracies find it particularly difficult to match "words and deeds." The final step in our analysis offers at least a partial explanation for this. Some studies suggest that advanced industrialized countries experience particularly serious difficulties in cutting emissions in the transportation sector, whereas poorer countries experience higher growth rates in GHG emissions from electricity and heat production. ${ }^{70}$ Large point sources (such as thermal power plants) are, in technical and monitoring/enforcement terms, easier to control than trans-

67. Germanwatch 2008 .

68. The results of all robustness checks are available from the authors.

69. Germanwatch 2008.

70. See, for example, Jahn 2008; and International Energy Agency 2007. 
TABLE 4. Results for overall indices of climate policy performance

\begin{tabular}{lcc}
\hline Variables & $\begin{array}{c}\text { Model 1 } \\
\text { GWSCORE }\end{array}$ & $\begin{array}{c}\text { Model 2 } \\
\text { CPPERFORM }\end{array}$ \\
\hline DEMOCRACY & $0.0520^{* * * *}$ & $0.0154 * * *$ \\
& $(0.0171)$ & $(0.0055)$ \\
CCI & $-0.3445 *$ & $-0.1883^{* * *}$ \\
& $(0.1766)$ & $(0.0557)$ \\
INCOME & -0.8427 & $-0.5024 * * *$ \\
& $(0.6667)$ & $(0.1146)$ \\
INCOME^2 & 0.0421 & $0.0264 * *$ \\
& $(0.0373)$ & $(0.0069)$ \\
GDPGROWTH & $-0.0285^{* *}$ & $-0.0121^{* *}$ \\
& $(0.0133)$ & $(0.0056)$ \\
CO 2 CAP1990 & $-0.0289^{* * *}$ & $-0.0028 *$ \\
& $(0.0064)$ & $(0.0017)$ \\
TRADEOPEN & $0.1436 * *$ & -0.0030 \\
& $(0.0564)$ & $(0.0180)$ \\
Constant & 4.8564 & $2.9467 * * *$ \\
& $(2.9606)$ & $(0.4688)$ \\
Observations & 55 & 171 \\
$R$-squared & 0.583 & 0.452 \\
& & \\
\hline
\end{tabular}

Notes: Robust standard errors in parentheses. * significant at $10 \%$;** significant at $5 \%$; *** significant at $1 \%$.

portation. Moreover, democratic governments may find it harder to restrict individual freedom by imposing constraints on personal mobility. To the extent that these assumptions hold true, we should observe a negative effect of democracy on emissions from transportation. Table 5 offers support for this argument.

The dependent variable is defined as the average annual growth of $\mathrm{CO}_{2}$ emissions per capita in 1990-2004 from energy and heat production as well as transportation. Again, we inverted the scale and standardized the dependent variables to a 0 to 1 range; higher values indicate smaller or negative emission growth rates. As to $\mathrm{CO}_{2}$ emissions from electricity and heat production, the biggest effects emanated from 1990 emission levels and the environmental Kuznets curve. Countries that had higher emission levels per capita in this sector in 1990 experienced lower growth rates thereafter, and poorer countries experienced higher emission growth rates than richer countries. Interestingly, democratic countries experienced greater difficulties in cutting emissions in the transportation sector. The effect of democracy was negative and significant. ${ }^{71}$ Moreover, better performance in policy out-

71. The 95 percent confidence interval for the democracy coefficient includes zero, but when we drop $1990 \mathrm{CO}_{2}$ levels because of their high correlation with income, the coefficient becomes significantly different from zero. 
TABLE 5. Democracy effects on $\mathrm{CO}_{2}$ emission trends in electricity and heat production and transport

\begin{tabular}{|c|c|c|}
\hline & $\begin{array}{c}\text { Model } 1 \\
\mathrm{CO}_{2} \text { ELECTR\&HEAT }\end{array}$ & $\begin{array}{c}\text { Model } 2 \\
\mathrm{CO}_{2} \text { TRANSPORT }\end{array}$ \\
\hline DEMOCRACY & $\begin{array}{c}0.0045 \\
(0.0082)\end{array}$ & $\begin{array}{c}-0.0238^{*} \\
(0.0120)\end{array}$ \\
\hline $\mathrm{CCI}$ & $\begin{array}{c}-0.1273 \\
(0.1196)\end{array}$ & $\begin{array}{c}-0.0143 \\
(0.0734)\end{array}$ \\
\hline INCOME & $\begin{array}{c}-0.4769 * * \\
(0.1849)\end{array}$ & $\begin{array}{c}-0.1192 \\
(0.2140)\end{array}$ \\
\hline INCOME $^{2}$ & $\begin{array}{l}0.0275^{* * *} \\
(0.0109)\end{array}$ & $\begin{array}{c}0.0102 \\
(0.0132)\end{array}$ \\
\hline GDPGROWTH & $\begin{array}{c}-0.0034 \\
(0.0067)\end{array}$ & $\begin{array}{c}-0.0122 \\
(0.0117)\end{array}$ \\
\hline $\mathrm{CO}_{2}$ ELECTR\&HEAT 1990 & $\begin{array}{l}0.0122 * * * \\
(0.0043)\end{array}$ & \\
\hline $\mathrm{CO}_{2}$ TRANSPORT 1990 & & $\begin{array}{c}0.0015 \\
(0.0168)\end{array}$ \\
\hline TRADEOPEN & $\begin{array}{r}-0.0147 \\
(0.0292)\end{array}$ & $\begin{array}{r}-0.0112 \\
(0.0305)\end{array}$ \\
\hline OUTPUT & $\begin{array}{c}-0.0214 \\
(0.0570)\end{array}$ & $\begin{array}{c}-0.1552 * \\
(0.0813)\end{array}$ \\
\hline Constant & $\begin{array}{l}2.6192 * * * \\
(0.7615)\end{array}$ & $\begin{array}{c}1.0396 \\
(0.8586)\end{array}$ \\
\hline Observations & 103 & 107 \\
\hline$R$-squared & 0.177 & 0.170 \\
\hline
\end{tabular}

Notes: Robust standard errors in parentheses. * significant at $10 \%$;** significant at $5 \% ; * * *$ significant at $1 \%$.

put terms had a significant, negative effect on performance in terms of emission trends in the transportation sector. This finding shows that the ambiguous democracy effect on policy outcomes shown in Table 3 may, at least to some extent, stem from the fact that democracies are finding it particularly difficult to restrict individual freedom and curb transport-related emissions. We return to this issue in the conclusions.

\section{Conclusion}

In focusing on the implications of democracy for the provision of global public goods, this article addresses an important gap in the international relations and comparative politics literature. The latter deals primarily with the effects of democracy on domestic public goods provision and dyadic international behavior. We have concentrated on climate change, one of the most important and complex global 
public goods challenges facing humankind. The empirical testing was done on a cross-section of 185 countries in 1990-2004.

The results show that the effect of democracy on political commitment to global public goods provision (policy output) is positive. In contrast, the democracy effects on policy outcomes, measured in terms of emission levels and trends, are ambiguous. The analysis of sectoral emissions suggests that the ambiguous democracy effect in the analysis of total emissions is at least in part due to the negative democracy effect on emissions from transportation. These results demonstrate that, in moving from political commitments to GHG reductions, the democracy effect has up to this point in time not been able to override countervailing forces that emanate from the free-rider problem, the discounting of future benefits of climate change mitigation, and other factors that cut against efforts to reduce emissions.

The research reported in this article has interesting implications for international relations theory as well as climate change policy. The implications for international relations theory are that ambiguous findings in the existing literature with respect to the effects of democracy on domestic public goods provision and dyadic international behavior can be identified also in the area of global public goods provision, particularly for policy outcomes. Studying political commitment and environmental behavior side by side thus produces insights that are missing in studies that concentrate only on one or the other dependent variable. In climate change policy, democracies are clearly more responsive at the political-commitment than at the problem-solving level, not only in absolute terms, but also relative to nondemocracies.

It would be interesting to explore whether more democratic countries experience larger "words-deeds" gaps in other policy areas, and whether there are systematic differences of this kind between domestic and international commitments and across different policy areas. The comparative politics and political economy literature allows for two competing hypotheses. ${ }^{72}$ One assumes that in democracies with a well-informed electorate and strong competition for political offices, policymakers who promise more than they can implement experience political costs, for example an increased risk of losing elections. The other assumes that growing mediatization of politics and other factors that have increased the extent of competition for electoral support motivate policymakers to become more "adventurous" with respect to political commitments. To the extent that voters are myopic and "overdosed" by competing information and political claims, policymakers in advanced democracies can get away lightly with increased "wordsdeeds" gaps.

The recent international relations literature tends to side with the first assumption. Several authors have argued that democracies have stronger domestic enforcement mechanisms than nondemocracies, and that their decisions to engage in international commitments will thus be more closely aligned with policy out-

72. See, for example, Persson and Tabellini 2000; and Kriesi 2008. 
comes. ${ }^{73}$ Von Stein hypothesizes that "democracies ... are more likely to keep their international promises-in large part because they only make promises they know they can keep." 74 The approach taken in this article, which uses a unified analytical framework to study policy output, outcome, and gaps between the two, helps in testing this claim without narrowing the focus to legally binding obligations and formal compliance. Hence it is more in line with the recent literature on the effectiveness of international regimes, which conceptualizes effectiveness primarily in terms of problem solving rather than legal compliance. ${ }^{75}$ In using selfselected political commitment levels rather than formal treaty obligations as the benchmark, it also avoids the "constrain or screen" problem inherent in studies focusing on formal treaty commitments and compliance. ${ }^{76}$ In contrast to empirical results on (positive) democracy effects on compliance in the human rights and monetary policy area ${ }^{77}$ our analysis shows that democracy is associated with a bigger implementation gap in climate change policy. This contrasting evidence appears quite worrying from a normative perspective. The remainder of this section thus concentrates on its policy implications.

In climate change policy, democracies have obviously had a slow start in moving from commitments to emission reductions. This should not come as a great surprise. Climate change is a much more complex challenge than most local or regional environmental degradation issues, such as air and water pollution. It is also characterized by a global free-rider problem.

However, there are signs that more democratic countries are likely to perform better over the long run in policy outcome terms as well. As argued in the theory section of this article, public and interest group demand for climate change mitigation is likely to be stronger in democracies than in nondemocracies. The available empirical evidence in fact suggests that public concern over climate change risks tends to be higher in democracies, independently of income. This is also true of environmental NGO activity. ${ }^{78}$ Moreover, democracies tend to have higher

73. See, for example, von Stein 2008 b.

74. Ibid, quotation from abstract.

75. See, for example, Helm and Sprinz 2000; Siegfried and Bernauer 2007.

76. See von Stein 2005 .

77. See, for example, von Stein 2008a.

78. The lack of large- $\mathrm{N}$ data for public demand for climate change mitigation prevents us from systematically testing whether democracy has a positive effect on such demand. However, we can muster some, albeit sketchy support from surveys, for example, the one carried out in about forty countries by the Program on International Policy Attitudes (PIPA); available at $\langle\mathrm{http}: / /$ www.pipa.org/ $/$. accessed 14 January 2009. The PIPA survey data covers the years 2003 and 2006. The respondents were asked whether "climate change or global warming, due to the greenhouse effect" is a serious problem. This survey measures public concern over climate change risks. We regressed this data on income and democracy and found that democracy has a significant, positive effect on such concern. We also examined the determinants of Greenpeace membership per capita (von Stein 2008a) and included this indicator in the models reported in Table 3. Greenpeace is well known for its strong position in favor of large GHG emission cuts. Its membership may serve as a proxy for how strong interest group pressure for climate change mitigation is. We found that democracy is a significant, positive predictor of Greenpeace membership independently of other potential determinants (for example, income). In 
income levels, and the available data shows that the environmental Kuznets curve for GHG emissions has already reached a turning point in most of the rich and democratic countries. Democracies are, independently of income, also more active in environmental monitoring and research and development ${ }^{79}$ - this increases knowledge about risks and generates new technologies that are more energy efficient. Democracies also tend to perform better in terms of sustainable development more broadly defined (for example, as measured in the form of the World Bank's Index of Adjusted Net Savings and the Center for International Earth Science Information Network's Environmental Performance Index) ${ }^{80}$ It is hard to see why this pattern should not extend to global environmental problems, such as climate change, at least in the long run. The evidence presented in this article is largely congruent with this argument. In combination with the assumption that democratic institutions are more likely to motivate policymakers to supply policies that meet public and interest group demand for climate change mitigation, these findings leave considerable room for optimism.

\section{References}

Aerni, Philipp. 2005. Private Management of Public Trust: The Changing Nature of Political Protest. Unpublished manuscript. Available at 〈http://www.iaw.agrl.ethz.ch/people〉. Accessed 14 January 2009.

Antweiler, Werner, Brian R. Copeland, and M. Scott Taylor. 2001. Is Free Trade Good for the Environment? American Economic Review 91 (4):877-908.

Barrett, Scott. 2005. Environment and Statecraft: The Strategy of Environmental Treaty-Making. Oxford, England: Oxford University Press.

Barrett, Scott, and Kathryn Graddy. 2000. Freedom, Growth, and the Environment. Environment and Development Economics 5 (4):433-56.

Bättig, Michèle B., Simone Brander, and Dieter M. Imboden. 2008. Measuring Countries' Cooperation Within the International Climate Change Regime. Environmental Science \& Policy 11 (6):478-89.

Bättig, Michèle B., Martin Wild, and Dieter M. Imboden. 2007. A Climate Change Index: Where Climate Change May Be Most Prominent in the 21st Century. Geophysical Research Letters 34 (L01705):1-6.

Beck, Ulrich. 1986. Risikogesellschaft. Frankfurt, Germany: Suhrkamp.

adding this indicator to the models reported in Table 3 we can assess whether NGO pressure has an effect on climate change policy, independent of democracy. We found that the effects of the other variables remained largely as they were, and that Greenpeace membership has an independent, positive effect on policy output but, surprisingly, a negative effect on policy outcome. The effects on emission levels and trends are insignificant. We view the negative effect on policy outcome as a potential selection effect: that is, Greenpeace may be able to mobilize more support in countries that lag behind in climate policy outcomes.

79. This assumption is supported by regressing ESIMIS, an indicator that captures how complete the raw data used in the construction of the Environmental Sustainability Index (ESI) is, on democracy and income. Data for this indicator is available at $\langle$ http://sedac.ciesin.columbia.edu/es/epi/downloads. html $\rangle$, accessed 14 January 2009. Controlling for income the effect of democracy is positive and significant. For information on the ESI, see Environmental Sustainability Index 2008.

80. See also Ward 2008. 
Bernauer, Thomas. 2003. Genes, Trade, and Regulation. The Seeds of Conflict in Food Biotechnology. Princeton, N.J.: Princeton University Press.

Bernauer, Thomas, and Ladina Caduff. 2004. In Whose Interest? Pressure Group Politics, Economic Competition and Environmental Regulation. Journal of Public Policy 24 (1):99-126.

Bernauer, Thomas, and Vally Koubi. 2009. Effects of Political Institutions on Air Quality. Ecological Economics 68 (5):1355-65.

Bernauer, Thomas, and Patrick Kuhn. Forthcoming. Is There an Environmental Version of the Kantian Peace? Insights from Water Pollution in Europe. European Journal of International Relations. Available at 〈http://www.ib.ethz.ch/docs〉. Accessed 27 January 2009.

British Petroleum (BP). 2007. BP Statistical Review of World Energy. Available at 〈http://www.bp.com/〉. Accessed 14 January 2009.

Bueno de Mesquita, Bruce, James D. Morrow, Randolph M. Siverson, and Alastair Smith. 2001. Political Competition and Economic Growth. Journal of Democracy 12 (1):58-72.

Bueno de Mesquita, Bruce, Alastair Smith, Randolph M. Siverson, and James D. Morrow. 2003. The Logic of Political Survival. Cambridge, Mass.: MIT Press.

Busch, Marc L. 2000. Democracy, Consultation, and the Paneling of Disputes Under GATT. Journal of Conflict Resolution 44 (4):425-46.

Cass, Loren R. 2006. The Failures of American and European Climate Policy: International Norms, Domestic Politics, and Unachievable Commitments. Albany: State University of New York Press.

Climate Analysis Indicators Tool (CAIT). 2008. World Resources Institute. Available at 〈http:// cait.wri.org/>. Accessed 14 January 2009.

Cole, Matthew A., and Eric Neumayer. 2005. Environmental Policy and the Environmental Kuznets Curve: Can Developing Countries Escape the Detrimental Consequences of Economic Growth? In Handbook of Global Environmental Politics, edited by Peter Dauvergne, 298-318. Cheltenham, England: Edward Elgar.

Congleton, Roger D. 1992. Political Institutions and Pollution Control. Review of Economics and Statistics 74 (3):412-21.

Dai, Xinyuan. 2006. The Conditional Nature of Democratic Compliance. Journal of Conflict Resolution 50 (5):690-713.

Desai, Uday. 1998. Ecological Policy and Politics in Developing Countries: Economic Growth, Democracy, and Environment. New York: State University of New York Press.

Diekmann, Andreas, and Axel Franzen. 1999. The Wealth of Nations and Environmental Concern. Environment and Behavior 31 (4):540-49.

Dorussen, Han, and Hugh Ward. 2008. Intergovernmental Organizations and the Kantian Peace: A Network Perspective. Journal of Conflict Resolution 52 (2):189-212.

Dryzek, John S. 1987. Rational Ecology: Environment and Political Economy. Oxford: Basil Blackwell.

Environmental Sustainability Index (ESI). 2008. Environmental Performance Measurement Project. New Haven, Conn.: Yale University. Available at 〈http://www.yale.edu/esi/〉. Accessed 14 January 2009.

Franzen, Axel, and Reto Meyer. 2004. Klimawandel des Umweltbewusstseins? Eine Analyse des ISSP 2000. Zeitschrift für Soziologie 33 (2):119-37.

Freedom House. 2006. Available at 〈www.freedomhouse.org $\rangle$. Accessed 14 January 2009.

Germanwatch. 2008. Climate Change Performance Index. Available at /http://www.germanwatch.org/ ccpi.htm $\rangle$. Accessed 14 January 2009.

Gleditsch, Kristian Skrede. 2006. Expanded Trade and GDP Data. Available at 〈http://privatewww. essex.ac.uk/ ksg/exptradegdp.html〉. Accessed 14 January 2009.

Gleditsch, Nils Petter, and Bjorn Otto Sverdrup. 2003. Democracy and the Environment. In Human Security and the Environment: International Comparisons, edited by Edward A. Page, and Michael Redclift, 45-70. Cheltenham, England: Edward Elgar.

Grossman, Gene M., and Alan B. Krueger. 1995. Economic Growth and the Environment. Quarterly Journal of Economics 110 (2):353-77.

Hafner-Burton, Emilie M., Jana von Stein, and Erik Gartzke. 2008. International Organizations Count. Journal of Conflict Resolution 52 (2):175-88. 
Hardin, Garrett. 1968. The Tragedy of the Commons. Science 162:1243-48.

Helm, Carsten, and Detlef F. Sprinz. 2000. Measuring the Effectiveness of International Environmental Regimes. Journal of Conflict Resolution 45 (5):630-52.

International Energy Agency (IEA). 2007. $\mathrm{CO}_{2}$ Emissions from Fuel Combustion 1971-2005. Paris: IEA.

IPCC (Intergovernmental Panel on Climate Change). 2007. Climate Change 2007. Report available at $\langle$ http://www.ipcc.ch〉. Accessed 14 January 2009.

Jahn, Detlef. 2008. The Politics of Climate Change. Paper presented at the 5th Annual General Conference of the European Consortium for Political Research, April, Rennes France.

Kriesi, Hanspeter. 2008. Vergleichende Politikwissenschaft. Baden-Baden, Germany: Nomos.

Li, Quan, and Rafael Reuveny. 2006. Democracy and Environmental Degradation. International Studies Quarterly 50 (4):935-56.

Maddison, Angus. 2007. Historical Statistics. Available at 〈http://www.ggdc.net/maddison/〉. Accessed 14 January 2009.

Marshall, Monty G., and Keith Jaggers. 2007. Polity IV Project: Political Regime Characteristics and Transitions. Available at 〈http://www.systemicpeace.org/polity/polity4.htm〉. Accessed 14 January 2009.

McGuire, Martin, and Mancur Olson. 1996. The Economics of Autocracy and Majority Rule: The Invisible Hand and the Use of Force. Journal of Economic Literature 34 (2):72-96.

Midlarsky, Manus I. 1998. Democracy and the Environment: An Empirical Assessment. Journal of Peace Research 35 (3):341-61.

Munck, Gerardo L., and Jay Verkuilen. 2002. Conceptualizing and Measuring Democracy: Evaluating Alternative Indices. Comparative Political Studies 35 (1):5-34.

Murdoch, James C., and Todd Sandler. 1997. The Voluntary Provision of a Pure Public Good: The Case of Reduced CFC Emissions and the Montreal Protocol. Journal of Public Economics 63:331-49.

Neumayer, Eric. 2002. Do Democracies Exhibit Stronger International Environmental Commitment? A Cross-Country Analysis. Journal of Peace Research 39 (2):139-64.

Olson, Mancur. 1968. The Logic of Collective Action: Public Goods and the Theory of Groups. New York: Schocken Books.

- 1982. The Rise and Decline of Nations: Economic Growth, Stagflation, and Social Rigidities. New Haven, Conn.: Yale University Press.

1993. Dictatorship, Democracy and Development. American Political Science Review 87 (3):567-76.

Oye, Kenneth A., and James H. Maxwell. 1994. Self-Interest and Environmental Management. Journal of Theoretical Politics 6 (4):593-64.

Paehlke, R. 1996. Environmental Challenges to Democratic Practice. In Democracy and the Environment: Problems and Prospects, edited by William M. Lafferty and James Meadowcroft, 18-38. Cheltenham, England: Edward Elgar.

Payne, Rodger A. 1995. Freedom and the Environment. Journal of Democracy 6 (3):41-55.

Persson, Torsten, and Guido Tabellini. 2000. Political Economics: Explaining Economic Policy. Cambridge, Mass.: MIT Press.

Plümper, Thomas, and Christian W. Martin. 2003. Democracy, Government Spending, and Economic Growth: A Political-Economic Explanation of the Barro Effect. Public Choice 117 (1-2):27-50.

Program on International Policy Attitudes (PIPA). 2006. Globe Scan Poll: Global Views on Climate Change Questionnaire and Methodology. Available at 〈http://www.pipa.org/onlinereports/ climatechange $\rangle$. Accessed 14 January 2009.

Przeworski, Adam. 2004. Institutions Matter? Government and Opposition 39 (2):527-40.

Roberts, Timmons J., Bradley C. Parks, and Alexis A. Vásquez. 2004. Who Ratifies Environmental Treaties and Why? Institutionalism, Structuralism and Participation by 192 Nations in 22 Treaties. Global Environmental Politics 4 (3):22-64.

Ross, Michael. 2006. Is Democracy Good for the Poor? American Journal of Political Science 50 (4):860-74. 
Sandler, Todd. 2004. Global Collective Action. Cambridge: Cambridge University Press.

Siegfried, Tobias, and Thomas Bernauer. 2007. Estimating the Performance of International Regulatory Regimes: Methodology and Empirical Application to International Water Management in the Naryn/Syr Darya Basin. Water Resources Research 43 (W11406, doi:10.1029/2006WR005738).

Social Learning Group. 2001. Learning to Manage Global Environmental Risks. Vol. 2, A Functional Analysis of Social Responses to Climate Change, Ozone Depletion, and Acid Rain. Cambridge, Mass.: MIT Press.

Sprinz, Detlef, and Tapani Vaahtoranta. 1994. The Interest-Based Explanation of International Environmental Policy. International Organization 48 (1):77-105.

Stern, Nicholas, Sir. 2007. Written Testimony to the U.S. Senate Committee on Energy and Natural Resources. Stern Review of the Economics of Climate Change. 110th Cong., 1st sess. 13 February.

Stigler, George J. 1971. The Theory of Economic Regulation. Bell Journal of Economics and Management Science 2 (1):3-21.

Torras, Mariano, and James K. Boyce. 1998. Income, Inequality, and Pollution: A Reassessment of the Environmental Kuznets Curve. Ecological Economics 25 (2):147-60.

Victor, David G. 2001. The Collapse of the Kyoto Protocol and the Struggle to Slow Global Warming. Princeton, N.J.: Princeton University Press.

Vogel, David. 1995. Trading Up: Consumer and Environmental Regulation in a Global Economy. Cambridge: Harvard University Press.

- 2005. The Market for Virtue: The Potential and Limits of Corporate Social Responsibility. Washington, D.C.: Brookings Institution Press.

von Stein, Jana. 2005. Do Treaties Constrain or Screen? Selection Bias and Treaty Compliance. American Political Science Review 99 (4):611-22.

2008a. The International Law and Politics of Climate Change: Ratification of the United Nations Framework Convention and the Kyoto Protocol. Journal of Conflict Resolution 52 (2):243-68.

- 2008b. Making Promises, Keeping Promises: Democracy, Ratification, and Compliance in International Human Rights Law. Unpublished manuscript, University of Michigan, Ann Arbor.

Ward, Hugh. 2008. Liberal Democracy and Sustainability. Environmental Politics 17 (3):386-409.

World Bank. 2006. World Development Indicators. Available at 〈www.worldbank.org/data〉. Accessed 28 January 2009. 